\title{
The effects of afforestation on soil bacterial communities in temperate grassland are modulated by soil chemical properties
}

\author{
Shu-Hong Wu ${ }^{\text {Corresp., }}{ }^{1}$, Bing-Hong Huang ${ }^{2}$, Jian Gao ${ }^{3}$, Siqi Wang ${ }^{1}$, Pei-Chun Liao ${ }^{\text {Corresp. }}{ }^{2}$ \\ ${ }^{1}$ School of Nature Conservation, Beijing Forestry University, Beijing, China \\ 2 Department of Life Science, National Taiwan Normal University, Taipei, Taiwan \\ 3 Faculty of Resources and Environment, Baotou Teachers' College, Inner Mongolia University of Science and Technology, Inner Mongolia, China \\ Corresponding Authors: Shu-Hong Wu, Pei-Chun Liao \\ Email address: wshuhong@bjfu.edu.cn, pcliao@ntnu.edu.tw
}

Grassland afforestation dramatically affects the abiotic, biotic, and ecofunction properties of the original ecosystems. Interference from afforestation might disrupt the stasis of soil physicochemical properties and the dynamic balance of microbiota. Some studies have suggested low sensitivity of soil properties and bacterial community to afforestation, but the apparent lack of a significant relationship is probably due to the confounding effects of the generalist habitat and rare bacterial communities. In this study, soil chemical and prokaryotic properties in a 30-year-old Mongolia pine (Pinus sylvestris var. mongolica Litv.) afforested region and adjacent grassland in Inner Mongolia were classified and quantified. Our results indicate that the high richness of rare microbes accounts for the alpha-diversity of the soil microbiome. Few OTUs of generalist (core bacteria) and habitat-specialist bacteria are present. However, the high abundance of this small number of OTUs governs the beta-diversity of the grassland and afforested land bacterial communities.

Afforestation has changed the soil chemical properties, thus indirectly affecting the soil bacterial composition rather than richness. The contents of soil $\mathrm{P}, \mathrm{Ca}^{2+}$, and $\mathrm{Fe}^{3+}$ account for differentially abundant OTUs such as Planctomycetes and subsequent changes in the ecofunctional potential of soil bacterial communities due to grassland afforestation. We conclude that grassland afforestation has changed the chemical properties and composition of the soil and ecofunctions of the soil bacterial community and that these effects of afforestation on the microbiome have been modulated by changes in soil chemical properties. 
1 The effects of afforestation on soil bacterial communities in temperate grassland are modulated by soil chemical properties

3

$6{ }^{1}$ School of Nature Conservation, Beijing Forestry University, No.35 Tsinghua East Road, Haidian District, Beijing 7 100083, China

8 2Department of Life Science, National Taiwan Normal University, No. 88 Ting-Chow Rd., Sec. 4, Taipei, Taiwan

9 'Faculty of Resources and Environment, Baotou Teachers' College, Inner Mongolia University of Science and 10 Technology, Inner Mongolia 014030, China

11

12

Short title: Afforestation effect on soil bacteria

13

14

15

16

17

18

19

20

21

22

23

24

25

\section{* Corresponding authors}

Dr. Shu-Hong Wu

Email:wshuhong@126.com

Tel: 86-10-6233-6853

Fax: 86-10-6233-62853

Dr. Pei-Chun Liao

Email: pcliao@ntnu.edu.tw

Tel: 886-2-77346330

Fax: 886-2-29312904 


\section{Abstract}

27 Grassland afforestation dramatically affects the abiotic, biotic, and ecofunction properties of the

28 original ecosystems. Interference from afforestation might disrupt the stasis of soil

29 physicochemical properties and the dynamic balance of microbiota. Some studies have suggested

30 low sensitivity of soil properties and bacterial community to afforestation, but the apparent lack

31 of a significant relationship is probably due to the confounding effects of the generalist habitat

32 and rare bacterial communities. In this study, soil chemical and prokaryotic properties in a 30-

33 year-old Mongolia pine (Pinus sylvestris var. mongolica Litv.) afforested region and adjacent

34 grassland in Inner Mongolia were classified and quantified. Our results indicate that the high

35 richness of rare bacteria accounts for the alpha-diversity of the soil prokaryotic microbiome. Few

36 OTUs of generalist (core bacteria) and habitat-specialist bacteria are present. However, the high

37 abundance of this small number of OTUs governs the beta-diversity of the grassland and

38 afforested land bacterial communities. Afforestation has changed the soil chemical properties,

39 thus indirectly affecting the soil bacterial composition rather than richness. The contents of soil P,

$40 \mathrm{Ca}^{2+}$, and $\mathrm{Fe}^{3+}$ account for differentially abundant OTUs such as Planctomycetes and subsequent

41 changes in the ecofunctional potential of soil bacterial communities due to grassland

42 afforestation. We conclude that grassland afforestation has changed the chemical properties and

43 composition of the soil and ecofunctions of the soil bacterial community and that these effects of

44 afforestation on the microbiome have been modulated by changes in soil chemical properties. 


\section{Introduction}

48 After a decline in forest coverage in China from roughly 40-60\% in remote antiquity (He et al. 492008 ) to only $8.6 \%$ due to war, urban construction, and reclamation, efforts in the last 30 years

50 by the Chinese government to promote afforestation have increased forest coverage to nearly

$5120 \%$ (State Forestry Administration of China 2011). However, these plantations are not

52 exclusively located at the original sites of deforestation, and consequently, these deforestation

53 and afforestation events have greatly changed the landscape and ecosystems of China (Ahrends

54 et al. 2017). Mongolia pine (Pinus sylvestris var. mongolica Litv.), an endemic tree in Inner

55 Mongolia including in Honghua'erji, is one of the main forestation species in temperate regions

56 of China. Scots pine (P. sylvestris L.), a relative of Mongolia pine that is widespread from

57 Western Europe to Eastern Siberia, is also an important tree in forestry (Krakau et al. 2013) and

58 is physiologically sensitive to environmental pollution (Chudzińska et al. 2014), geographic

59 weather variation (Oleksyn et al. 2003) and climate change (Hurme et al. 1997; Savolainen et al.

60 2004). Studies have demonstrated that Scots pine and, by reasonable extension, Mongolia pine

61 have broad, plastic adaptability in response to environmental heterogeneity, supporting the wide

62 use of these trees in afforestation.

63 Grassland afforestation is an artificial and direct change in vegetation that alters both the above-

64 and underground ecosystems, including abiotic changes (Li et al. 2016; Peng et al.

65 2014)(Khamzina et al. 2016; Lafleur et al. 2015), biotic changes (Ma et al. 2013) (Márquez et al.

66 2015; Pedley et al. 2014)(Gunina et al. 2017; Šnajdr et al. 2013; Xiao et al. 2017), and

67 ecofunction changes (Lu et al. 2017; Ren et al. 2016) (Cibils et al. 2015). Land use is a

68 significant determinant of runoff and soil redistribution processes (Arnáez et al. 2015), and soil 
69 microbial species responses may be sensitive to compositional changes in both species and

70 ecofunctions (Xiao et al. 2017). However, these underground biological changes are sometimes

71 ascribed to changes in litter amount and chemistry that stimulate the development of the fungal

72 community rather than the bacterial community (Klein et al. 1995). The response of the

73 prokaryotic microbiome to changes in vegetation type is small, likely because bacterial

74 assemblies are based mainly on functional genes rather than species (Burke et al. 2011), and the

75 changes in soil properties due to afforestation are relatively small and occur slowly (Gunina et al.

76 2017; Jangid et al. 2011). In addition, abundant bacterial "core species" with highly conserved

77 core functions (Falkowski et al. 2008) and rarely occurring species (Ai et al. 2013) may act as

78 confounders in statistical analyses of the effects of afforestation or soil properties on prokaryotic

79 microbiome change. Therefore, habitat generalists (core species) and specialists (divergent

80 species) in bacterial communities must be classified before analysis, particularly when using

81 high-throughput sequencing (HTS) technology (e.g., 16S rRNA metagenomic sequencing),

82 which can generate huge amounts of data, to outline the composition and structure of bacterial

83 communities (Székely \& Langenheder 2014).

84 Although the environmental bacterial composition may be sensitive to environmental variation,

85 the effects of these bacterial composition changes on ecofunction remain unclear. A

86 comprehensive review demonstrated that the soil microbial composition varies to alter

87 acquisition, metabolism, and degradation processes in response to changes in soil phosphorus (P)

88 due to grassland afforestation (Chen et al. 2008). More importantly, environmental conditions

89 and existing microbial diversity determine the ecological function and nutrient transformation

90 efficiency of soil microbiota (Zechmeister-Boltenstern et al. 2015). Therefore, quantifying the

91 effects of afforestation on changes in soil properties, bacterial composition, and ecofunctions 
92 would accelerate the understanding of plant-soil-microbe interactions.

93 In this study, to quantify the effect of afforestation on soil properties and soil bacterial

94 composition and functions, soil chemical and bacterial compositions were measured in an

95 afforested region and adjacent grassland. Based on previous studies that have demonstrated

96 functional assembly of bacterial communities (Burke et al. 2011) and a small response of

97 bacterial communities to afforestation, with low sensitivity to soil properties (Gunina et al. 2017;

98 Jangid et al. 2011; Klein et al. 1995), we hypothesized the following: (1) The soil prokaryotic

99 microbiome is indirectly affected by afforestation mediated by soil chemical properties. If so,

100 soil chemical properties should differ significantly between afforested and grassland sites and

101 should be correlated with the composition of the soil prokaryotic microbiome. (2) Soil bacterial

102 ecofunctions are more sensitive to changes in vegetation type than changes in soil bacterial

103 composition. If so, significant differentiation of the predicted ecofunctional potential should be

104 observed between afforested and grassland sites. To test these hypotheses, the 16S rRNA

105 metagenomes of the afforested and adjacent grassland soil bacterial communities were

106 sequenced, and the relative abundances of bacteria and predicted ecophysiological functions

107 were quantified by multivariate and regression analyses. Since root exudates did not significantly

108 affect the bacterial assemblages in a previous study (Wu et al. 2018), we excluded the effect of

109 root exudates in this study. Based on these analyses, we provide a possible explanation of the

110 link between soil chemical properties and bacterial community change in grassland afforestation. 


\section{Materials and Methods}

\section{Study sites and sampling}

115 The study site was located $6 \mathrm{~km}$ west of the town of Honghua'erji in an artificial forest produced

116 by seedling afforestation in a large area of thin grassland (savanna, N48.257443 ${ }^{\circ}$

$117 \mathrm{E} 119.996448^{\circ}$ ). The annual precipitation is approximately $390 \mathrm{~mm}$, and the mean annual

118 temperature is roughly $-2.4^{\circ} \mathrm{C}$. The elevation is approximately $740-1100 \mathrm{~m}$. The forest coverage

119 is as high as $69.8 \%$ in the forest regions of the nature reserve, while the Honghua'erji grassland is

120 a bare grassland ecosystem that is mainly composed of weedy species such as Stipa baicalensis,

121 Festuca ovina, and Carex pediformis (Wen et al. 2002). The field experiments were approved by

122 the Honghua'erji Nature Reserve (permit number 200/66150221). The tree ages of the Mongolian

123 pines in this afforestation forest range from 27 to 33 years, with a diameter at breast height (DBH)

124 of $21.21 \pm 4.19 \mathrm{~cm}(12.09 \sim 32.10 \mathrm{~cm})$ and tree height of $12.86 \pm 0.86(11.2 \sim 14.6 \mathrm{~m})$.

125 At the study site, we collected soil samples from 20 quadrants, including 10 inside the forest (i.e.,

126 forest soils) and 10 in the adjacent grassland (i.e., grassland soils). Each quadrant was roughly

$127100 \mathrm{~m}^{2}$. At each location, $1-\mathrm{kg}$ soil samples were collected at a depth of $50 \mathrm{~cm}$ in permeable bags

128 of nylon mesh from 10 quadrants located 10 to $100 \mathrm{~m}$ from each other (Fig. S1). This depth was

129 chosen because the major microbiome composition and the major transition of soil

130 physicochemical characteristics are located at a soil depth of approximately $50 \mathrm{~cm}$ (Fierer et al.

131 2003). All equipment was sterilized by an autoclave. The soil samples were separated into two

132 parts: one part was dried for quantification of soil physicochemical properties, and the other was

133 used to quantify the microbiome. The latter samples were stored in RNAguardian stabilization

134 solution (MBGEN Biosciences, Taipei, Taiwan) on ice immediately after collection until transfer

135 to the laboratory, where the samples were stored at $-20^{\circ} \mathrm{C}$ before metagenomic DNA extraction. 


\section{Quantifying soil chemical properties}

138 Organic carbon (C) was measured by the external-heat potassium dichromate oxidation method, 139 and total nitrogen content $(\mathrm{N})$ was measured by the Kjeldahl distillation method. The inductively 140 coupled plasma (ICP) method was used with soils digested in a mixture of $\mathrm{HF}-\mathrm{HClO}_{4}-\mathrm{HNO}_{3}$ to

141 quantify the contents of the soil elements $\mathrm{K}^{+}, \mathrm{P}, \mathrm{Ca}^{2+}, \mathrm{Fe}^{3+}, \mathrm{Mg}^{2+}$, and $\mathrm{Na}^{+}$. Soil $\mathrm{pH}$ was

142 determined using a Sartorius pH meter PB-10 (Germany) with a soil:water ratio of 1:2.5. All soil

143 properties were determined and quantified by the State Key Laboratory of Vegetation and

144 Environmental Change, Institute of Botany, Chinese Academy Sciences.

\section{16S rRNA metagenome sequencing}

147 Bacterial metagenomic DNA was extracted with an EZNA ${ }^{\circledR}$ Soil DNA Kit (Qiagen, Valencia, $148 \mathrm{CA}$, USA), and the concentration was adjusted to $50 \mathrm{ng} \mathrm{ml}^{-1}$ via dilution. The metagenomic 149 DNA was quantified using Qubit ${ }^{\circledR} 2.0$ (Invitrogen, Life Technologies, CA, USA). The primers $150341 \mathrm{~F}$ (5'-CCTACGGGNGGCWGCAG-3') and 805R (5'-GACTACHVGGGTATCTAATCC-3') 151 were used to amplify the V3-V4 hypervariable 16S rRNA region (Mizrahi-Man et al. 2013), and 152 the PCR products were used to construct a DNA library with the Roche GS FLX Titanium 153 emPCR kit (Roche Applied Science). The DNA libraries were then sequenced by Sangon 154 Biotech Co. (Shanghai, China) on an Illumina MiSeq 2X300. The sequencing procedures 155 followed the manufacturer's instructions.

156 Before analysis, the raw HTS data were cleaned by removing sequence fragments shorter than $157200 \mathrm{bp}$ or with missing barcodes or polyN or polyA/T in the Ribosomal Database Project (RDP) 
158 (Cole et al. 2007). We also discarded reads with PHRED quality scores $<$ Q25 (Ewing \& Green

159 1998; Ewing et al. 1998). The Mothur package was used to remove non-prokaryotic sequences

160 and de-noise and trim the sequences (Mothur ver. 1.30.1,

161 http://www.mothur.org/wiki/MiSeq_SOP (Schloss et al. 2009)). Chimeric sequences were

162 removed using Uchime (Edgar et al. 2011). After quality filtering, we clustered sequences using

163 a criterion of $>97 \%$ sequence similarity as operational taxonomic units (OTUs) defined as

164 representing the same species by the UPARSE pipeline (http://drive5.com/uparse/) (Edgar 2013)

165 and closed-reference OTU picking. We estimated the relative abundances (RAs) of the soil

166 microbiome according to $16 \mathrm{~S}$ rRNA metagenome sequencing. The rarefied OTU table was

167 generated using Qiime (Caporaso et al. 2010) and deposited in Mendeley

168 (doi:10.17632/gjskh8wswz.1). All steps were conducted by Sangon Biotech Co. (Shanghai,

169 China) according to their pipeline (https://www.sangon.com/services_ngs_metseq.html). Each

170 OTU was annotated and classified according to the RDP classifier and SILVA database. The raw

171 sequence data were deposited in NCBI GenBank under Bioproject PRJNA317430 (Accession

172 number: SAMN04607375).

173

174 Predictive functional profiling of bacterial communities

175 PICRUSt v. 1.0.0, a functional prediction tool for estimating shared gene content according to 176 the corresponding bacterial phylogeny, was used to predict the functional potential of each

177 sample (Langille et al. 2013). PICRUSt generates the composition of gene families for each

178 metagenome using an extended ancestral-state reconstruction algorithm. The online version of

179 PICRUSt implemented in Galaxy (https://huttenhower.sph.harvard.edu/galaxy/) was used to 180 assist the algorithms. The quality-filtered sequences were assigned to an OTU table against the 
181 Greengenes v. 13.5 OTU database (DeSantis et al. 2006) for PICRUSt prediction implemented in

182 QIIME v. 1.8.0 (Caporaso et al. 2010). Each OTU was normalized by its copy number. The

183 functional contribution of each OTU member was reconstructed and predicted by mapping the

$18416 \mathrm{~S}$ sequences to their nearest reference genome. 'Virtual' metagenomes with gene content

185 abundance were then generated using the Kyoto Encyclopedia of Genes and Genomes (KEGG)

186 Ortholog and Clusters of Orthologous Groups (COGs) databases.

187

188 Statistical analyses

189 All statistical analyses were conducted in R (R CoreTeam 2013). This study included two types

190 of measurements, the soil chemical properties and soil bacterial communities (i.e., relative

191 abundances of bacterial OTUs), and one treatment, grassland afforestation (i.e., vegetation type:

192 grassland vs forest). Due to inequality of variance (certain factors such as $\mathrm{Na}^{+}$and $\mathrm{Ca}^{2+}$ deviated

193 from equal variance in Levene's test), we first assessed the differences in soil properties between

194 vegetation types by the nonparametric Mann-Whitney U (MW) test using R. In addition, to

195 determine whether the diversity of prokaryotic microbiome differs after afforestation, we

196 calculated diversity indexes such as the Shannon-Wiener $H$, reciprocal Simpson's index $1 / D$,

197 species richness, and Pielou's evenness for each of the soil bacterial communities and compared

198 them between afforested and grassland sites by the Mann-Whitney U test. We also adopted the R

199 package DESeq2 (Love et al. 2014) to identify OTUs that were differentially abundant between

200 the afforested and grassland sites. A logistic regression model was further used to determine if

201 each of the soil properties predicted the grassland-afforestation treatment. The likelihood ratio

202 test (LRT) was performed to identify the best-fitting model of the logistic regression. To test the

203 hypotheses of a stochastic process of bacterial assembly (random distribution model) or 
204 resource-governed assembly (niche-based mechanism), we used Rank-Abundance Dominance 205 (RAD) analysis to display logarithmic relative species abundances against species rank order 206 (McGill et al. 2007). Bray-Curtis distance-based redundancy analysis (dbRDA) implemented in 207 the R package vegan (Dixon \& Palmer 2003) was used to examine the explanatory proportions 208 of the treatment (vegetation type) for these two measurements (soil properties and microbiomes).

209 Because soil chemical properties can also affect the soil bacterial communities (Stutter \& 210 Richards 2012), we further performed a partial dbRDA to assess the effects of grassland 211 afforestation on the soil bacterial communities conditioned by soil chemical properties and the 212 effects of the soil chemical properties on the soil bacterial communities conditioned by 213 vegetation type using the Bray-Curtis distance. The best model were chosen via forward 214 selection by the ordistep function implemented in the R package vegan (Dixon \& Palmer 2003).

215 Type II ANOVA was used to evaluate the fit of the model of each constraint factor. We further 216 identified divergent bacteria (i.e., forest and grassland specialists) using the supermajority rule 217 ( $>2 / 3$ difference in abundance) with the assistance of the multinomial species classification 218 method (CLAM) test (Chazdon et al. 2011). The soil elements that significantly explained the 219 soil bacterial communities by partial dbRDA were then used as independent factors to predict the 220 abundance of bacterial specialists by the generalized linear model (GLM). We also performed 221 hierarchical cluster analysis (H-cluster) and discriminant analysis of principal components 222 (DAPC) to illustrate the grouping patterns between afforested and grassland sites using the R 223 package adegenet (Jombart 2008). Because the ecophysiological functions (COGs and KEGG 224 modules) of the soil microbiomes were also predicted, all tests were repeated by replacing the 225 soil bacterial OTUs with the relative abundances of the COGs and KEGG modules. All R codes 226 and input files have been deposited as Mendeley data 
227 (https://data.mendeley.com/datasets/gjskh8wswz/1).

228

229 Results

230 Effects of afforestation on soil chemical properties

231 To characterize the soil chemical properties, the contents of eight elements (organic C, total N, P, $232 \mathrm{~K}^{+}, \mathrm{Ca}^{2+}, \mathrm{Mg}^{2+}, \mathrm{Fe}^{3+}$, and $\mathrm{Na}^{+}$) and the $\mathrm{pH}$ value of each soil sample were determined (Table 1).

233 Among these soil variables, the contents of $\mathrm{C}, \mathrm{P} \mathrm{Ca}^{2+}, \mathrm{Mg}^{2+}$, and $\mathrm{Fe}^{3+}$ were significantly higher

234 in the forest soils than in the grassland soils $(P<0.01)$, and the $\mathrm{pH}$ of the grassland soils was

235 significantly higher than the $\mathrm{pH}$ of the forest soils $(P=0.031)$ (Fig. 1). To estimate the

236 explanatory proportions of the afforestation effect on the variance of soil properties, we

237 performed dbRDA using vegetation type (i.e., forest and grassland) as the independent factor.

238 Vegetation type significantly explained $50.18 \%$ of the variance of soil properties $(P=0.002$,

239 Table 2 and Fig. S2), indicating that afforestation has changed the soil properties.

240 If the soil elements are altered after afforestation, the contents of soil elements will predict the

241 vegetation type (i.e., afforestation effect). To test this hypothesis, we compared the simple

242 logistic regression (SLR) model using a single soil element as the independent factor and the

243 multivariate logistic regression (MLR) model using all soil elements as independent factors (i.e.

244 the full model M1) to the empty (null) model M0. Most of the SLR models and M1 rejected the 245 null model M0 $(P<0.005)$, except the SLR models with K (LRT: $P=0.084)$ or Na (LRT: $P=$

2460.108 ) as the independent factor. We further compared the SLR models with each single soil

247 element (C, N, $\mathrm{P}, \mathrm{Ca}^{2+}, \mathrm{Mg}^{2+}, \mathrm{Fe}^{3+}$, and $\left.\mathrm{pH}\right)$ as the independent factor with the MLR model using

248 all $\mathrm{C}, \mathrm{N}, \mathrm{P}, \mathrm{Ca}^{2+}, \mathrm{Mg}^{2+}, \mathrm{Fe}^{3+}$, and $\mathrm{pH}$ as independent factors (full model M2) by LRT to 
249 determine which individual factors might be related to afforestation. The SLR models with $\mathrm{Mg}$

250 or Fe as the independent factor could not be rejected by M2 $(P=0.278$ and 0.130 , respectively,

251 Fig. 2). Although the other SLR models with $\mathrm{C}, \mathrm{N}, \mathrm{P}, \mathrm{Ca}^{2+}$, or $\mathrm{pH}$ as the independent factor were

252 rejected by M2, none of the independent factors in M2 could significantly predict the presence of

253 forestation $\left(Z<10^{-6}, P>0.9999\right.$ in each term). These results indicated that the contents of $\mathrm{Mg}^{2+}$

$254\left(0.456 \pm 0.099\right.$ and $0.313 \pm 0.035 \mathrm{~g} / \mathrm{kg}$ in forest and grassland soils, respectively) and $\mathrm{Fe}^{3+}$

$255(8.355 \pm 1.047$ and $5.607 \pm 1.308$ g.kg-1 in forest and grassland soils, respectively) could singly

256 reflect the changes in soil properties due to afforestation (Table 1 and Fig. 2).

257

258 Afforestation effects on the relative abundances of soil bacteria

259 Overall, a total of 694,993 sequences were obtained after rarefaction analysis $(314,923$ for

260 grassland and 380,070 for forest). Divergence of the soil microbiome was inferred by significant

261 or marginal differences in the diversity indices (Shannon-Wiener index $H, \mathrm{~W}=26, P=0.0753$;

262 Reciprocal Simpson's index 1/D: $\mathrm{W}=23, P=0.0432$; Pielou's evenness $J: \mathrm{W}=8.5, P=0.0019$,

263 Table 3). However, no difference was estimated in the species richness of the soil microbiome

264 between forest and grassland ( $\mathrm{W}=50, P=1$, Table 3 ). Hence, we used RA as an indicator to

265 compare the microbiomes of the soil samples (Fig. S3). H-cluster and DAPC (five first PCs of

266 PCA used, which conserved $70 \%$ of the variance of the bacterial RA) presented similar patterns

267 of clear divergence of soil microbiomes between the forest and grassland (Fig. 3). A total of 350

268 OTUs with an adjusted $P$-value $<0.01$ exhibited twofold changes between forest and grassland

269 vegetation (178 OTUs were higher in grassland, while 172 were higher in forest). The

270 differentially abundant OTUs were only from the most abundant phyla (Proteobacteria,

271 Acidobacteria, and Verrucomicrobia) and Planctomycetes. These results confirm that the soil 
272 bacterial composition has changed due to grassland afforestation despite no change in bacterial 273 richness.

274 Because the close-reference OTU picking strategy discards samples that do not bin with $97 \%$ 275 similarity, assignments of different OTUs were rarely found among different samples. We 276 performed the CLAM test (Chazdon et al. 2011) to classify these OTUs as four types of bacteria 277 using the supermajority (2/3) rule: too-rare bacteria, generalist bacteria, and grassland- and 278 forest-specialist bacteria. In this classification, a large proportion of OTUs (95.46\%) belonged to 279 the too-rare bacteria, which accounted for $38.42 \%$ and $36.73 \%$ of the abundance of grassland and 280 forest soil bacteria, respectively; only $2.98 \%$ of the OTUs were generalists, but they accounted 281 for $35.55 \%$ and $35.88 \%$ of the abundance of grassland and forest soil bacteria, respectively. Only $2821.56 \%$ of the OTUs belonged to specialists, of which $1061(0.7 \%)$ and $1224(0.8 \%)$ bacterial 283 OTUs were identified as forest and grassland specialists, respectively. The RA of grassland284 specialist bacteria was $22.84 \%$ in grassland soils and $2.84 \%$ in forest soils, while the RA of 285 forest-specialist bacteria was 3.19\% in grassland soils and $24.55 \%$ in forest soils.

286 We further used the RAs of the bacterial OTUs as the dependent response to access the impact of 287 afforestation on the soil bacterial communities. When vegetation type was used as the categorical 288 independent factor, $16.3 \%$ of the variance of bacterial RA was explained significantly $(P=$ 289 0.001). However, the significant explanatory effect of vegetation type was lost after removing 290 (conditioning on) soil properties $(P=0.466$, Table 2$)$. When soil properties were used as a 291 constraint factor, $64.4 \%$ of the variance of bacterial RA was explained by soil properties, in 292 which organic C (11.4\% explanation), $\mathrm{P}(10.0 \%), \mathrm{Ca}^{2+}(9.0 \%), \mathrm{Mg}^{2+}(7.1 \%)$, and $\mathrm{Fe}^{3+}(10.5 \%)$ 293 significantly fit the model by type II ANOVA (Table 2). Similar significant explanations by C 294 (6.7\%), $\mathrm{P}(9.5 \%), \mathrm{Ca}^{2+}(8.8 \%), \mathrm{Mg}^{2+}(6.7 \%)$, and $\mathrm{Fe}^{3+}(5.4 \%)$ were obtained when the effect of 
295 vegetation type was removed (i.e., partial dbRDA, Table 2). In addition, when conducting

296 forward model selection, the bacterial RA was best explained by vegetation type, $\mathrm{Ca}^{2+}, \mathrm{Mg}^{2+}$,

$297 \mathrm{Na}^{+}$and $\mathrm{pH}$ (constrained proportion: 48.07\%). However, although $\mathrm{pH}$ is important in shaping the

298 soil microbiome at continental scales (Lauber et al. 2009), the pH did not vary among vegetation

299 types (forest: 6.3-6.36, grassland: 6.13-6.35) in our fine-scale study. There was no collinearity of

$300 \mathrm{pH}$ with other factors (variance inflation factor (VIF): 1.125). Therefore, we do not discuss the

301 importance of $\mathrm{pH}$ in our study. These analyses suggested that afforestation has changed the soil

302 chemical properties, with changes in at least $\mathrm{Ca}^{2+}$ and $\mathrm{Mg}^{2+}$ in all analyses, thus indirectly

303 affecting the soil bacterial communities (Fig. S2 and S3).

Effects of soil properties on the divergence of bacterial phyla between forest and grassland 306 soils

307

To identify the divergent soil bacteria, the habitat-specialist bacterial phyla were classified under

the supermajority rule (i.e., 2/3 majority). At the phylum level, five phyla were habitat specialists, including one forest specialist (Thaumarchaeota, phylum RA: 2.3\%) and four grassland specialists (Chloroflexi, Fibrobacteres, Nitrospirae, and Parcubacteria, 9.3\%). The forest-

311 specialist phylum Thaumarchaeota belongs to Archaea, while the four grassland specialists are 312 Eubacteria.

313 We further tested the effects of soil properties on the abundance of these habitat specialists by

314 GLM. Because organic $\mathrm{C}, \mathrm{P}, \mathrm{Ca}^{2+}, \mathrm{Mg}^{2+}$, and $\mathrm{Fe}^{3+}$ significantly explained the RA of soil bacteria 315 in dbRDA, these five soil variables were used as independent predictors in GLM. The variances 316 of the bacterial abundance of the sampled soils were significantly or marginally significantly 
317 greater than the means, suggesting overdispersion of these responses $(P=0.056,0.001,0.051$,

3180.002 , and 0.002; alpha $=52.675,25.871,1.065,23.101$, and 76.612 in Thaumarchaeota,

319 Chloroflexi, Fibrobacteres, Nitrospirae, and Parcubacteria, respectively). Hence, we used the

320 quasi-Poisson model for GLM, which led to the same coefficient estimates as the standard

321 Poisson model but with adjustment of the dispersion parameter for overdispersion. Under the

322 quasi-Poisson model, $\mathrm{Fe}^{3+}$ content was marginally correlated with the abundance of the forest

323 specialist Thaumarchaeota; for the grassland specialists, the P content was correlated with the

324 abundances of all four phyla (Table 4). In addition, $\mathrm{C}, \mathrm{Ca}^{2+}$, and $\mathrm{Mg}^{2+}$ were significantly

325 correlated with Chloroflexi, $\mathrm{Fe}^{3+}$ was significantly correlated with Nitrospirae, and $\mathrm{Ca}^{2+}$ and

$326 \mathrm{Mg}^{2+}$ were marginally correlated with Parcubacteria (Table 4).

327

328

\section{Afforestation effects on the soil ecophysiological functions predicted by soil microbiome}

329

330

331

332

333

334

335

336

337

338

339

To understand the ecophysiological functions of the soil bacterial communities, we predicted their functional composition using $16 \mathrm{~S}$ rRNA gene and databases of reference genomes. A total of 4659 clusters of orthologous groups (COGs) and 306 KEGG modules (Level-3 KEGG

orthology) were identified. Similar to the analyses for testing the effects of afforestation and soil properties on the soil bacterial communities, we used vegetation type and soil elements as predictors to test the explanatory proportion and significance of each predictor on the RAs of the COGs and KEGG modules. dbRDA indicated that $22.0 \%$ and $21.2 \%$ of the variation of COGs and KEGG modules was significantly explained by vegetation type, respectively, whereas the explanatory proportion decreased to $3.4 \%$ and $4.5 \%$ when conditioning the soil-property effect (Table 5). Soil properties explained $83.0 \%$ and $82.4 \%$ of the variation of the COGs and KEGG modules in dbRDA, respectively, in which $\mathrm{C}, \mathrm{P}, \mathrm{Ca}^{2+}, \mathrm{Mg}^{2+}, \mathrm{Fe}^{3+}$, and $\mathrm{N}$ significantly or 
340 marginally fit the model according to type II ANOVA (Table 5). When conditioned on

341 vegetation type, the explanatory proportion decreased slightly to $64.4 \%$ and $65.8 \%$ for the COGs

342 and KEGG modules, respectively, and the remaining significant fitting factors were $\mathrm{P}, \mathrm{Ca}^{2+}$, and $343 \mathrm{Fe}^{3+}$ (Table 5).

344 Among all COGs, 44 and 21 were identified as forest- and grassland-predominant COG

345 categories by CLAM analysis, respectively. Most of the forest-predominant categories are

346 involved in post-translational regulation, such as ubiquitin or E3 ligase, while many categories in

347 grassland are membrane proteins or are involved in cell transport. By contrast, among all KEGG

348 modules, only two forest-predominant categories and no grassland-predominant categories were

349 identified. Further testing of the correlation of soil elements with these specialist COGs and

350 KEGG modules revealed that 50 of the 65 COGs and both KEGG modules were significantly

351 correlated with at least one soil element under Poisson or quasi-Poisson regression. These

352 significant correlations indicate that soil properties, particularly $\mathrm{P}, \mathrm{Ca}^{2+}$, and $\mathrm{Fe}^{3+}$, account for the 353 changes in ecophysiological functional due to grassland afforestation.

355 Discussion

356 The closure of the tree canopy and increased litter accumulation that accompany the ecosystem 357 change from grassland to forest may directly alter the soil environment (Bond \& Midgley 2012; 358 Cunningham et al. 2015). The significantly higher contents of soil chemical factors (C, P, $\mathrm{Ca}^{2+}$, $359 \mathrm{Mg}^{2+}, \mathrm{Fe}^{3+}$, and $\mathrm{pH}$ ) in the Mongolian pine plantation areas than in the unplanted region suggest 360 a great influence of grassland afforestation on secondary salinization. Soil mineral elements are 361 usually increased in tree-plantation regions where groundwater is insufficient to meet water 
362 requirements (Nosetto et al. 2008). High contents of soil elements in a forest suggest not only a

363 larger amount of litter biomass but also a rapid decomposition rate of pine litters compared to

364 other broadleaf flora (Berger et al. 2015). However, despite significant differences in the

365 contents of soil elements between forest and grassland, these soil elements, except $\mathrm{Mg}^{2+}$ and $\mathrm{Fe}^{3+}$

366 (Fig. 2), could not singly predict the ecosystem change due to afforestation by logistic regression

367 analysis.

368 Significantly high predictable contents of $\mathrm{Fe}^{3+}$ and $\mathrm{Mg}^{2+}$ in forest soils reflect the characteristics

369 of litter and humus accumulation in forests (Song et al. 2008). Litter decomposition accelerates

370 the conversion and accumulation of soil non-organic elements (Fenchel et al. 2012b). In $2^{\text {nd }- \text { to- }}$

$3713^{\text {rd }}$-year needle litters of $P$. sylvestris L., a decrease in the rate of biomass loss but an increase in

372 the release of $\mathrm{Fe}^{3+}$ and $\mathrm{Mg}^{2+}$ were recorded (De Marco et al. 2007). Consequently, we suggest

373 that the high contents of $\mathrm{Fe}^{3+}$ and $\mathrm{Mg}^{2+}$ in the forest soils of our study sites are due to the long,

374 steady accumulation and decomposition of needle litter. The soil element cycling affects and is

375 affected by the composition of the soil microbiota (Fenchel et al. 2012b). For example, the iron

376 bacteria family Comamonadaceae, which was represented by the genera Delftia, Comamonas,

377 Acidovorax, and Albidiferax in our sampling, are able to deposit iron metal oxides under natural

378 conditions. These bacteria were present in soil for both vegetation types. They were slightly

379 more abundant in forest samples and can grow rapidly in iron-rich and acidic substrates

380 (Emerson et al. 2015; Fenchel et al. 2012a). These results indicate that alteration of these

381 chemical properties may lead to a change in the composition of the soil prokaryotic microbiome.

382 The distributions of the soil bacterial abundances in our samples best fit to Zipf and Zipf-

383 Mandelbrot rank abundance models (Table 6 and Fig. S4). The Zipf and Zipf-Mandelbrot rank

384 abundance models belong to the family of random-branching processes; these models suggest 
385 that individuals are always derived from ancestor individuals (McGill et al. 2007) and that

386 microbial community assembly is explained by the niche-based mechanism (McGill et al. 2007;

387 Mendes et al. 2014). These models indicate that decades of grassland afforestation have

388 generated soil properties that provide a divergent but stable resource supply for the soil bacterial

389 community, although a strong effect of depth on the structure of bacterial communities should be

390 recognized (Eilers et al. 2012).

391 Classification by the supermajority rule revealed that generalist bacteria represented more than

$3922 / 3$ of the total counts but $<3 \%$ of bacterial OTUs. The low richness but relatively high

393 abundance of generalists suggests that a great proportion of residents utilize broad resources or

394 are highly tolerant of the environment (Verberk 2011). It has been suggested that microbes that

395 are present in all or the majority of microbial communities with high abundance represent the

396 core set of genes responsible for key elements of most metabolic pathways (Falkowski et al.

397 2008). Similarly, specialist bacteria exhibited $<1 \%$ richness but accounted for approximately $1 / 5$

398 to $1 / 4$ of the RA in the grassland and forest soils. These specialist OTUs with low richness and

399 high abundance are probably more susceptible than generalists to environmental change. Since

400 the original vegetation was scattered grasses, the grassland specialists rarely found in forest soils

401 were those selected against by the afforestation effect; by contrast, forest specialists should be

402 enriched after forestation. The environmental differences (e.g., the contents of soil C, P, $\mathrm{Ca}^{2+}$,

$403 \mathrm{Mg}^{2+}$, and $\mathrm{Fe}^{3+}$, Table 2) could result in resource (niche) divergence to differentiate the bacterial

404 composition descended from the original bacterial communities, reflecting the bacterial

405 abundance distribution in the Zipf and Zipf-Mandelbrot models (Table 6).

406 In particular, the $\mathrm{Fe}^{3+}$ content was significantly correlated with the abundance of the forest-

407 specialist Archaea phylum Thaumarchaeota, and P was correlated with the four grassland- 
408 specialist Eubacteria phyla Chloroflexi, Fibrobacteres, Nitrospirae, and Parcubacteria (Table 4), 409 suggesting that these two soil elements are key factors differentiating soil bacterial composition.

410 Thaumarchaeota encodes the genes ammonia monooxygenase A (amoA, encoding subunit A of

411 AMO) and amoB, which are distantly related to one another and similar to the bacterial amo

412 gene for ammonia oxidation (Stieglmeier et al. 2014). The high abundance of amo $A$ and its

413 transcripts suggests that ammonia-oxidizing archaea (AOA) are present in higher numbers than

414 ammonia-oxidizing bacteria (Shen et al. 2008) and that nitrogen cycling is enhanced in the forest

415 (Konneke et al. 2005; Stieglmeier et al. 2014). A high abundance of AOA with a high content of

$416 \mathrm{Fe}^{3+}$ (e.g., ferrate, an ammonia oxidation reagent) could accelerate ammonia oxidation (Sharma

417 et al. 1998).

418 Soil P is closely related to plant growth (Shen et al. 2011), but microbes that transform P to

419 improve uptake by plants are also influenced by both plant species and soil type (Chen et al.

420 2008). P metabolism is often related to the fungal community (Beever \& Burns 1981; Rodríguez

421 \& Fraga 1999). In this study, the specialists that were correlated with soil P content were

422 primarily not responsible for P transformation but were light and aerobic thermophiles (e.g.,

423 Chloroflexi), symbionts within ruminant animals (e.g., Fibrobacteres), or involved in the

424 nitrogen cycle (e.g., Nitrospirae). Although not directly linked to P content, these bacterial

425 ecofunctions reflect the differences between grassland and forest ecosystems. The major changes

426 in the canopy, amounts of litterfall, plant composition, and root-bacteria interactions due to

427 grassland afforestation may explain the differences in soil P content as well as the abundances of

428 these bacterial phyla (Chen et al. 2008; Li et al. 2004).

429 By contrast, the significant differences in $H, 1 / D$, and $J$ but not richness between the grassland 430 and forest soil microbiomes suggest that the change in the soil microbiome is due to a difference 
431 in species RA rather than species number. A high proportion of "too-rare" bacterial OTUs (95\%

432 richness) accounted for $>1 / 3$ of the RA of soil bacteria, reflecting transient changes in bacteria in

433 the environments. This rarity could result from stochasticity (Ai et al. 2013), fitness trade-off

434 (Gobet et al. 2012; Gudelj et al. 2010), or biological interactions (García-Fernández et al. 2004;

435 Narisawa et al. 2008; Schluter et al. 2015). These rare bacteria are still relevant in ecological

436 functions, including bacterial community assembly and function and biogeochemical cycling

437 (Jousset et al. 2017). The high richness of rare bacteria contributes to the alpha-diversity of the

438 soil bacterial communities.

439 Based on the dbRDA of the relationships among vegetation type, soil properties, and bacterial

440 composition, we concluded that grassland afforestation has affected the soil chemical properties

441 (Table 2), soil microbiome composition and ecofunction potential. Post-translational systems

442 may increase the heterogeneity of the soil prokaryotic microbiome and facilitate the coexistence

443 of different bacterial species via functional regulation (Spallek et al. 2009). In addition, these

444 effects of afforestation on the microbiome were modulated by changes in soil chemical

445 properties (Table 2 and Table 5). The changes in chemical properties led to differential

446 abundance of low-taxonomic-level OTUs. For example, Planctomycetes, which was

447 differentially abundant between forest and grassland in our data, are sensitive to changes in soil

448 management and physicochemical properties (Buckley et al. 2006). This conclusion was reached

449 because the explanation of soil microbiome by vegetation type decreased or was even lost when

450 conditioned on soil properties (Table 2). Albeit indirectly, afforestation indeed altered the

451 ecofunction of the soil microbiome (Table 5).

452 As discussed above, soil chemical properties interact with the soil bacterial communities.

453 Because the original vegetation before forestation was grassland, the changes in the soil 
454 properties are probably attributable to the vegetation changes produced by afforestation. Several

455 studies have suggested that afforestation can influence biotic and abiotic changes in micro- and

456 macro-ecosystems (Jousset et al. 2017; Nosetto et al. 2008; Wang et al. 2016; Zheng et al. 2017).

457 Here, we suggest that the underground biotic change was indirectly affected by forestation

458 mediated by soil property changes (Table 2 ), especially the contents of soil $\mathrm{P}, \mathrm{Ca}^{2+}$, and $\mathrm{Fe}^{3+}$,

459 which are further related to ecofunction changes in soil microbiomes for different vegetation

460 types (Table 5 and Table S1). These results are similar to the bacterial abundance changes and

461 compositional shifts reported for a long-term poplar plantation, which were suggested to be

462 highly correlated with the changes in soil properties caused by afforestation (Zheng et al. 2017).

463 Soil bacterial composition has been suggested to be more closely related to plant diversity-

464 controlled abiotic soil properties because of the highly resilient characteristics of bacterial

465 communities due to their fast life cycle (de Vries et al. 2012; Lange et al. 2014).

\section{Conclusions}

467 The change in vegetation type was linked, at least in part, to potential ecofunction changes in the

468 soil bacterial communities, despite an indirect impact on bacterial composition and the

469 calculation of the ecofunction potential from the bacterial composition. Aboveground changes

470 such as abiotic factors and biotic activities may be responsible for these changes in underground

471 ecofunctions. According to our study, afforestation may change the soil contents and

472 subsequently affect the ecofunctions and alpha- and beta-diversity of bacterial communities.

473 However, the relatively small proportion of bacterial specialists and high proportion of bacterial

474 generalists with respect to ecofunction among the bacterial OTUs indicates that the vegetation

475 change preserved a high proportion of the core functions of the soils (Li et al. 2004). This

476 preservation occurred because the core functional genes were distributed widely across a variety 
477 of bacterial taxa. However, the high proportion of functions that were correlated with changes in

478 soil properties indicates that bacterial ecofunctions are highly sensitive to environmental change.

479 Future work could focus on the link between anthropogenic actions on vegetation and indicator

480 species such as Planctomycetes or iron bacteria such as Comamonadaceae. These links could be

481 validated by quantitative analyses (e.g., qPCR) to determine how changes in the structure of key

482 bacteria lead to ecofunction changes after land cover change.

483

484 Acknowledgments

485 We thank Dr. Dawn Schmidt for English editing of the manuscript.

486

487 Funding

488 This research was financially supported by the Fundamental Research Funds for the Central

489 Universities (to SHW) and supported by the Ministry of Science and Technology, Taiwan

490 (MOST 105-2628-B-003-001-MY3 and MOST 105-2628-B-003-002-MY3) (to PCL). This

491 article was also subsidized by the National Taiwan Normal University (NTNU).

492

493

494

495

496

497

498

499

500

501

\section{References}

Ahrends A, Hollingsworth PM, Beckschäfer P, Chen H, Zomer RJ, Zhang L, Wang M, and Xu J. 2017. China's fight to halt tree cover loss. Proceedings of the Royal Society B: Biological Sciences 284: 20162559.

Ai D, Chu C, Ellwood MDF, Hou R, and Wang G. 2013. Migration and niche partitioning simultaneously increase species richness and rarity. Ecological Modelling 258:33-39. http://dx.doi.org/10.1016/j.ecolmodel.2013.03.001

Arnáez J, Lana-Renault N, Lasanta T, Ruiz-Flaño P, and Castroviejo J. 2015. Effects of farming terraces on hydrological and geomorphological processes. A review. CATENA 128:122-134. http://dx.doi.org/10.1016/i.catena.2015.01.021

502

503

Beever RE, and Burns DJW. 1981. Phosphorus uptake, storage and utilization by fungi. In: Woolhouse HW, ed. Advances in Botanical Research: Academic Press, 127-219. 
504

505

506

507

508

509

510

511

512

513

514

515

516

517

518

519

520

521

522

523

524

525

526

527

528

529

530

531

532

533

534

535

536

537

538

539

540

541

542

543

544

545

546

547

548

549

Berger TW, Duboc O, Djukic I, Tatzber M, Gerzabek MH, and Zehetner F. 2015. Decomposition of beech (Fagus sylvatica) and pine (Pinus nigra) litter along an Alpine elevation gradient: Decay and nutrient release. Geoderma 251-252:92-104. 10.1016/j.geoderma.2015.03.024

Bond WJ, and Midgley GF. 2012. Carbon dioxide and the uneasy interactions of trees and savannah grasses. Philosophical Transactions of the Royal Society B: Biological Sciences 367:601-612.

Buckley DH, Huangyutitham V, Nelson TA, Rumberger A, and Thies JE. 2006. Diversity of Planctomycetes in soil in relation to soil history and environmental heterogeneity. Applied and Environmental Microbiology 72:4522-4531. 10.1128/AEM.00149-06

Burke C, Steinberg P, Rusch D, Kjelleberg S, and Thomas T. 2011. Bacterial community assembly based on functional genes rather than species. Proceedings of the National Academy of Sciences 108:14288-14293.

Caporaso JG, Kuczynski J, Stombaugh J, Bittinger K, Bushman FD, Costello EK, Fierer N, Pena AG, Goodrich JK, Gordon JI, Huttley GA, Kelley ST, Knights D, Koenig JE, Ley RE, Lozupone CA, McDonald D, Muegge BD, Pirrung M, Reeder J, Sevinsky JR, Turnbaugh PJ, Walters WA, Widmann J, Yatsunenko T, Zaneveld J, and Knight R. 2010. QIIME allows analysis of high-throughput community sequencing data. Nature Methods 7:335-336. 10.1038/nmeth.f.303

Chazdon RL, Chao A, Colwell RK, Lin SY, Norden N, Letcher SG, Clark DB, Finegan B, and Arroyo JP. 2011. A novel statistical method for classifying habitat generalists and specialists. Ecology 92:1332-1343. Doi $10.1890 / 10-1345.1$

Chen CR, Condron LM, and Xu ZH. 2008. Impacts of grassland afforestation with coniferous trees on soil phosphorus dynamics and associated microbial processes: A review. Forest Ecology and Management 255:396-409. http://dx.doi.org/10.1016/i.foreco.2007.10.040

Chen F-S, Zeng D-H, Fahey TJ, and Liao P-F. 2010. Organic carbon in soil physical fractions under different-aged plantations of Mongolian pine in semi-arid region of Northeast China. Applied Soil Ecology 44:42-48. https://doi.org/10.1016/i.apsoil.2009.09.003

Chudzińska E, Diatta JB, and Wojnicka-Półtorak A. 2014. Adaptation strategies and referencing trial of Scots and black pine populations subjected to heavy metal pollution. Environmental Science and Pollution Research 21:2165-2177. 10.1007/s11356-013-2081-3

Cibils L, Principe R, Márquez J, Gari N, and Albariño R. 2015. Functional diversity of algal communities from headwater grassland streams: How does it change following afforestation? Aquatic Ecology 49:453-466. 10.1007/s10452-015-9538-z

Cole JR, Chai B, Farris RJ, Wang Q, Kulam-Syed-Mohideen AS, McGarrell DM, Bandela AM, Cardenas E, Garrity GM, and Tiedje JM. 2007. The ribosomal database project (RDP-II): introducing myRDP space and quality controlled public data. Nucleic Acids Research 35:D169-172. 10.1093/nar/gkl889

Cunningham SC, Mac Nally R, Baker PJ, Cavagnaro TR, Beringer J, Thomson JR, and Thompson RM. 2015. Balancing the environmental benefits of reforestation in agricultural regions. Perspectives in Plant Ecology, Evolution and Systematics 17:301-317. http://dx.doi.org/10.1016/j.ppees.2015.06.001

De Marco A, Vittozzi P, Rutigliano FA, and Virzo De Santo A. 2007. Nutrient dynamics during decomposition of four different pine litters. OPTIONS MÉDITERRANÉENNES SÉRIE A: SÉMINAIRES MÉDITERRANÉENS 75:73-77.

de Vries FT, Manning P, Tallowin JRB, Mortimer SR, Pilgrim ES, Harrison KA, Hobbs PJ, Quirk H, Shipley B, Cornelissen JHC, Kattge J, and Bardgett RD. 2012. Abiotic drivers and plant traits explain landscape-scale patterns in soil microbial communities. Ecology Letters 15:1230-1239. 10.1111/j.1461-0248.2012.01844.x

DeSantis TZ, Hugenholtz P, Larsen N, Rojas M, Brodie EL, Keller K, Huber T, Dalevi D, Hu P, and Andersen GL. 2006. Greengenes, a chimera-checked 16S rRNA gene database and workbench compatible with ARB. Appl Environ Microbiol 72:5069-5072. 10.1128/AEM.03006-05

Dixon P, and Palmer MW. 2003. VEGAN, a package of R functions for community ecology. Journal of Vegetation Science 14:927-930. 10.1658/1100-9233(2003)014[0927:vaporf]2.0.co;2 
550

551

552

553

554

555

556

557

558

559

560

561

562

563

564

565

566

567

568

569

570

571

572

573

574

575

576

577

578

579

580

581

582

583

584

585

586

587

588

589

590

591

592

593

Edgar RC. 2013. UPARSE: highly accurate OTU sequences from microbial amplicon reads. Nature Methods 10:996. 10.1038/nmeth.2604

https://www.nature.com/articles/nmeth.2604\#supplementary-information

Edgar RC, Haas BJ, Clemente JC, Quince C, and Knight R. 2011. UCHIME improves sensitivity and speed of chimera detection. Bioinformatics 27:2194-2200. 10.1093/bioinformatics/btr381

Eilers KG, Debenport S, Anderson S, and Fierer N. 2012. Digging deeper to find unique microbial communities: The strong effect of depth on the structure of bacterial and archaeal communities in soil. Soil Biology and Biochemistry 50:58-65. https://doi.org/10.1016/i.soilbio.2012.03.011

Emerson D, Scott JJ, Benes J, and Bowden WB. 2015. Microbial iron oxidation in the arctic tundra and its implications for biogeochemical cycling. Applied and Environmental Microbiology 81:8066-8075. 10.1128/AEM.02832-15

Ewing B, and Green P. 1998. Base-calling of automated sequencer traces using Phred. II. error probabilities. Genome Research 8:186-194. 10.1101/gr.8.3.186

Ewing B, Hillier L, Wendl MC, and Green P. 1998. Base-calling of automated sequencer traces using Phred.I. Accuracy assessment. Genome Research 8:175-185. 10.1101/gr.8.3.175

Falkowski PG, Fenchel T, and Delong EF. 2008. The microbial engines that drive earth's biogeochemical cycles. Science 320:1034-1039.

Fenchel T, King GM, and Blackburn TH. 2012a. Chapter 1 - Bacterial Metabolism. Bacterial Biogeochemistry (Third Edition). Boston: Academic Press, 1-34.

Fenchel T, King GM, and Blackburn TH. 2012b. Chapter 6 - Biogeochemical Cycling in Soils. Bacterial Biogeochemistry (Third Edition). Boston: Academic Press, 89-120.

Fierer N, Schimel JP, and Holden PA. 2003. Variations in microbial community composition through two soil depth profiles. Soil Biology and Biochemistry 35:167-176. https://doi.org/10.1016/S0038-0717(02)00251-1

García-Fernández JM, de Marsac NT, and Diez J. 2004. Streamlined regulation and gene loss as adaptive mechanisms in Prochlorococcus for optimized nitrogen utilization in oligotrophic environments. Microbiology and Molecular Biology Reviews 68:630-638.

Gobet A, Boer SI, Huse SM, van Beusekom JEE, Quince C, Sogin ML, Boetius A, and Ramette A. 2012. Diversity and dynamics of rare and of resident bacterial populations in coastal sands. ISME Journal 6:542-553. http://www.nature.com/ismej/journal/v6/n3/suppinfo/ismej2011132s1.html

Gudelj I, Weitz JS, Ferenci T, Claire Horner-Devine M, Marx CJ, Meyer JR, and Forde SE. 2010. An integrative approach to understanding microbial diversity: from intracellular mechanisms to community structure. Ecology Letters 13:1073-1084. 10.1111/j.1461-0248.2010.01507.x

Gunina A, Smith AR, Godbold DL, Jones DL, and Kuzyakov Y. 2017. Response of soil microbial community to afforestation with pure and mixed species. Plant and Soil 412:357-368. 10.1007/s11104-016-3073-0

He F, Ge Q, Dai J, and Rao Y. 2008. Forest change of China in recent 300 years. Journal of Geographical Sciences 18:59-72. 10.1007/s11442-008-0059-8

Holford ICR. 1997. Soil phosphorus: its measurement, and its uptake by plants. Australian Journal of Soil Research 35:227-240. 10.1071/S96047

http://www.publish.csiro.au/?paper=\$96047

Hurme P, Repo T, Savolainen O, and Pääkkönen T. 1997. Climatic adaptation of bud set and frost hardiness in Scots pine (Pinus sylvestris). Canadian Journal of Forest Research 27:716-723. 10.1139/x97-052

Hurme P, Sillanpää MJ, Arjas E, Repo T, and Savolainen O. 2000. Genetic basis of climatic adaptation in Scots pine by bayesian quantitative trait locus analysis. Genetics 156:1309-1322.

Jangid K, Williams MA, Franzluebbers AJ, Schmidt TM, Coleman DC, and Whitman WB. 2011. Land-use history has a 
594

595

596

597

598

599

600

601

602

603

604

605

606

607

608

609

610

611

612

613

614

615

616

617

618

619

620

621

622

623

624

625

626

627

628

629

630

631

632

633

634

635

636

637

638

639

stronger impact on soil microbial community composition than aboveground vegetation and soil properties. Soil Biology and Biochemistry 43:2184-2193. http://dx.doi.org/10.1016/i.soilbio.2011.06.022

Jombart T. 2008. adegenet: a R package for the multivariate analysis of genetic markers. Bioinformatics 24:14031405. 10.1093/bioinformatics/btn129

Jousset A, Bienhold C, Chatzinotas A, Gallien L, Gobet A, Kurm V, Kusel K, Rillig MC, Rivett DW, Salles JF, van der Heijden MGA, Youssef NH, Zhang X, Wei Z, and Hol WHG. 2017. Where less may be more: how the rare biosphere pulls ecosystems strings. ISME Journal 11:853-862. 10.1038/ismej.2016.174

Khamzina A, Lamers JPA, and Martius C. 2016. Above- and belowground litter stocks and decay at a multi-species afforestation site on arid, saline soil. Nutrient Cycling in Agroecosystems 104:187-199. 10.1007/s10705016-9766-1

Klein DA, McLendon T, Paschke MW, and Redente EF. 1995. Saprophytic fungal-bacterial biomass variations in successional communities of a semi-arid steppe ecosystem. Biology and Fertility of Soils 19:253-256. 10.1007/BF00336168

Konneke M, Bernhard AE, de la Torre JR, Walker CB, Waterbury JB, and Stahl DA. 2005. Isolation of an autotrophic ammonia-oxidizing marine archaeon. Nature 437:543-546. http://www.nature.com/nature/journal/v437/n7058/suppinfo/nature03911 S1.html

Krakau U-K, Liesebach M, Aronen T, Lelu-Walter M-A, and Schneck V. 2013. Scots Pine (Pinus sy/vestris L.). In: Pâques LE, ed. Forest Tree Breeding in Europe: Current State-of-the-Art and Perspectives. Dordrecht: Springer Netherlands, 267-323.

Lafleur B, Labrecque M, Arnold AA, and Bélanger N. 2015. Organic carbon accumulation in topsoil following afforestation with willow: emphasis on leaf litter decomposition and soil organic matter quality. Forests 6:769-793. 10.3390/f6030769

Lange M, Habekost M, Eisenhauer N, Roscher C, Bessler H, Engels C, Oelmann Y, Scheu S, Wilcke W, Schulze E-D, and Gleixner G. 2014. Biotic and abiotic properties mediating plant diversity effects on soil microbial communities in an experimental grassland. PLOS ONE 9:e96182. 10.1371/journal.pone.0096182

Langille MGI, Zaneveld J, Caporaso JG, McDonald D, Knights D, Reyes JA, Clemente JC, Burkepile DE, Vega Thurber RL, Knight R, Beiko RG, and Huttenhower C. 2013. Predictive functional profiling of microbial communities using 16S rRNA marker gene sequences. Nature Biotechnology 31:814-821. 10.1038/nbt.2676

http://www.nature.com/nbt/journal/v31/n9/abs/nbt.2676.htm|\#supplementary-information

Lauber CL, Hamady M, Knight R, and Fierer N. 2009. Pyrosequencing-based assessment of soil pH as a predictor of soil bacterial community structure at the continental scale. Applied and Environmental Microbiology 75:5111-5120. 10.1128/aem.00335-09

Li Q, Lee Allen H, and Wollum AG. 2004. Microbial biomass and bacterial functional diversity in forest soils: effects of organic matter removal, compaction, and vegetation control. Soil Biology and Biochemistry 36:571-579. http://dx.doi.org/10.1016/i.soilbio.2003.12.001

Li Y, Zhao M, Mildrexler DJ, Motesharrei S, Mu Q, Kalnay E, Zhao F, Li S, and Wang K. 2016. Potential and Actual impacts of deforestation and afforestation on land surface temperature. Journal of Geophysical Research: Atmospheres 121:14,372-314,386. 10.1002/2016JD024969

Love MI, Huber W, and Anders S. 2014. Moderated estimation of fold change and dispersion for RNA-seq data with DESeq2. Genome Biology 15:550. 10.1186/s13059-014-0550-8

Lu S, Zhang Y, Chen C, Xu Z, and Guo X. 2017. Plant-soil interaction affects the mineralization of soil organic carbon: evidence from 73-year-old plantations with three coniferous tree species in subtropical Australia. Journal of Soils and Sediments 17:985-995. 10.1007/s11368-016-1602-3

Ma E, Liu A, Li X, Wu F, and Zhan J. 2013. Impacts of vegetation change on the regional surface climate: A scenariobased analysis of afforestation in Jiangxi Province, China. Advances in Meteorology 2013:796163. $10.1155 / 2013 / 796163$ 
640

641

642

643

644

645

646

647

648

649

650

651

652

653

654

655

656

657

658

659

660

661

662

663

664

665

666

667

668

669

670

671

672

673

674

675

676

677

678

679

680

681

682

683

684

685

McGill BJ, Etienne RS, Gray JS, Alonso D, Anderson MJ, Benecha HK, Dornelas M, Enquist BJ, Green JL, He F, Hurlbert AH, Magurran AE, Marquet PA, Maurer BA, Ostling A, Soykan CU, Ugland KI, and White EP. 2007. Species abundance distributions: moving beyond single prediction theories to integration within an ecological framework. Ecology Letters 10:995-1015. 10.1111/j.1461-0248.2007.01094.x

Mendes LW, Kuramae EE, Navarrete AA, van Veen JA, and Tsai SM. 2014. Taxonomical and functional microbial community selection in soybean rhizosphere. ISME Journal 8:1577-1587. 10.1038/ismej.2014.17

Mizrahi-Man O, Davenport ER, and Gilad Y. 2013. Taxonomic classification of bacterial 16S rRNA genes using short sequencing reads: evaluation of effective study designs. PLOS ONE 8:e53608. 10.1371/journal.pone.0053608

Márquez JA, Cibils L, Principe RE, and Albariño RJ. 2015. Stream macroinvertebrate communities change with grassland afforestation in central Argentina. Limnologica - Ecology and Management of Inland Waters 53:17-25. http://dx.doi.org/10.1016/i.limno.2015.05.002

Narisawa N, Haruta S, Arai H, Ishii M, and Igarashi Y. 2008. Coexistence of antibiotic-producing and antibioticsensitive bacteria in biofilms is mediated by resistant bacteria. Applied and Environmental Microbiology 74:3887-3894.

Nosetto MD, Jobbágy EG, Tóth T, and Jackson RB. 2008. Regional patterns and controls of ecosystem salinization with grassland afforestation along a rainfall gradient. Global Biogeochemical Cycles 22:GB2015. 10.1029/2007GB003000

Oleksyn J, Reich PB, Zytkowiak R, Karolewski P, and Tjoelker MG. 2003. Nutrient conservation increases with latitude of origin in European Pinus sylvestris populations. Oecologia 136:220-235. 10.1007/s00442-003$1265-9$

Pedley SM, Martin RD, Oxbrough A, Irwin S, Kelly TC, and O'Halloran J. 2014. Commercial spruce plantations support a limited canopy fauna: Evidence from a multi taxa comparison of native and plantation forests. Forest Ecology and Management 314:172-182. http://dx.doi.org/10.1016/i.foreco.2013.12.010

Peng S-S, Piao S, Zeng Z, Ciais P, Zhou L, Li LZX, Myneni RB, Yin Y, and Zeng H. 2014. Afforestation in China cools local land surface temperature. Proceedings of the National Academy of Sciences of the United States of America 111:2915-2919.

Ren C, Sun P, Kang D, Zhao F, Feng Y, Ren G, Han X, and Yang G. 2016. Responsiveness of soil nitrogen fractions and bacterial communities to afforestation in the Loess Hilly Region (LHR) of China. Scientific Reports 6:28469. $10.1038 /$ srep28469

https://www.nature.com/articles/srep28469\#supplementary-information

Rodríguez H, and Fraga R. 1999. Phosphate solubilizing bacteria and their role in plant growth promotion. Biotechnology Advances 17:319-339. https://doi.org/10.1016/S0734-9750(99)00014-2

Savolainen O, Bokma F, Garća-Gil R, Komulainen P, and Repo T. 2004. Genetic variation in cessation of growth and frost hardiness and consequences for adaptation of Pinus sylvestris to climatic changes. Forest Ecology and Management 197:79-89. http://dx.doi.org/10.1016/i.foreco.2004.05.006

Schloss PD, Westcott SL, Ryabin T, Hall JR, Hartmann M, Hollister EB, Lesniewski RA, Oakley BB, Parks DH, Robinson CJ, Sahl JW, Stres B, Thallinger GG, Van Horn DJ, and Weber CF. 2009. Introducing mothur: open-source, platform-independent, community-supported software for describing and comparing microbial communities. Appl Environ Microbiol 75:7537-7541. 10.1128/AEM.01541-09

Schluter J, Nadell CD, Bassler BL, and Foster KR. 2015. Adhesion as a weapon in microbial competition. ISME Journal 9:139-149. 10.1038/ismej.2014.174

Sharma VK, Bloom JT, and Joshi VN. 1998. Oxidation of ammonia by ferrate(vi). Journal of Environmental Science and Health, Part A 33:635-650. 10.1080/10934529809376752

Shen J-p, Zhang L-m, Zhu Y-g, Zhang J-b, and He J-z. 2008. Abundance and composition of ammonia-oxidizing bacteria and ammonia-oxidizing archaea communities of an alkaline sandy loam. Environmental 
686

687

688

689

690

691

692

693

694

695

696

697

698

699

700

701

702

703

704

705

706

707

708

709

710

711

712

713

714

715

716

717

718

719

720

721

722

723

724

725

726

727

728

729

Microbiology 10:1601-1611. 10.1111/j.1462-2920.2008.01578.x

Shen J, Yuan L, Zhang J, Li H, Bai Z, Chen X, Zhang W, and Zhang F. 2011. Phosphorus dynamics: From soil to plant. Plant Physiology 156:997-1005.

Šnajdr J, Dobiášová P, Urbanová M, Petránková M, Cajthaml T, Frouz J, and Baldrian P. 2013. Dominant trees affect microbial community composition and activity in post-mining afforested soils. Soil Biology and Biochemistry 56:105-115. http://dx.doi.org/10.1016/i.soilbio.2012.05.004

Song $B$, Yin $X$, Zhang $Y$, and Dong W. 2008. Dynamics and relationships of $\mathrm{Ca}, \mathrm{Mg}$, Fe in litter, soil fauna and soil in Pinus koraiensis-broadleaf mixed forest. Chinese Geographical Science 18:284-290. 10.1007/s11769-0080284-1

Spallek T, Robatzek S, and Göhre V. 2009. How microbes utilize host ubiquitination. Cellular Microbiology 11:14251434. doi:10.1111/j.1462-5822.2009.01346.x

State Forestry Administration of China. 2011. China National Progress Report to the UNFF Secretariat on the implementation of NLBI and other relevant resolutions. In: Administration SF, editor. Beijing: S. F. A. China.

StiegImeier M, Alves RJE, and Schleper C. 2014. The Phylum Thaumarchaeota. In: Rosenberg E, DeLong EF, Lory S, Stackebrandt E, and Thompson F, eds. The Prokaryotes: Other Major Lineages of Bacteria and The Archaea. Berlin, Heidelberg: Springer Berlin Heidelberg, 347-362.

Stutter MI, and Richards S. 2012. Relationships between soil physicochemical, microbiological properties, and nutrient release in buffer soils compared to field soils. Journal of Environmental Quality 41:400-409. $10.2134 /$ jeq2010.0456

Székely AJ, and Langenheder S. 2014. The importance of species sorting differs between habitat generalists and specialists in bacterial communities. FEMS Microbiology Ecology 87:102-112. 10.1111/1574-6941.12195

Team RC. 2013. R: A language and environment for statistical computing.

Verberk WCEP. 2011. Explaining general patterns in species abundance and distributions. Nature Education Knowledge 3:38.

Wang F, Zhu W, and Chen H. 2016. Changes of soil C stocks and stability after 70-year afforestation in the Northeast USA. Plant and Soil 401:319-329. 10.1007/s11104-015-2755-3

Wen W, Maruyama N, Bo-wen L, Morimoto H, and Zhong-xin G. 2002. Relationships between bird communities and vegetation structure in Honghua'erji, northern inner Mongolia. Journal of Forestry Research 13:294298. 10.1007/BF02860095

Wu S-H, Huang B-H, Huang C-L, Li G, and Liao P-C. 2018. The Aboveground vegetation type and underground soil property mediate the divergence of soil microbiomes and the biological interactions. Microbial Ecology 75:434-446. 10.1007/s00248-017-1050-7

Xiao H, Li Z, Dong Y, Chang X, Deng L, Huang J, Nie X, Liu C, Liu L, Wang D, Liu Q, and Zhang Y. 2017. Changes in microbial communities and respiration following the revegetation of eroded soil. Agriculture, Ecosystems \& Environment 246:30-37. https://doi.org/10.1016/j.agee.2017.05.026

Zechmeister-Boltenstern S, Keiblinger KM, Mooshammer M, Peñuelas J, Richter A, Sardans J, and Wanek W. 2015. The application of ecological stoichiometry to plant-microbial-soil organic matter transformations. Ecological Monographs 85:133-155. 10.1890/14-0777.1

Zeng DH, Hu YL, Chang SX, and Fan ZP. 2009. Land cover change effects on soil chemical and biological properties after planting Mongolian pine (Pinus sylvestris var. mongolica) in sandy lands in Keerqin, northeastern China. Plant and Soil 317:121-133. 10.1007/s11104-008-9793-z

Zhao Q, Zeng DH, Lee DK, He XY, Fan ZP, and Jin YH. 2007. Effects of Pinus sy/vestris var. mongolica afforestation on soil phosphorus status of the Keerqin Sandy Lands in China. Journal of Arid Environments 69:569-582. https://doi.org/10.1016/i.jaridenv.2006.11.004 
730

731

732

733

734

735
Zheng J, Chen J, Pan G, Wang G, Liu X, Zhang X, Li L, Bian R, Cheng K, and Zheng J. 2017. A long-term hybrid poplar plantation on cropland reduces soil organic carbon mineralization and shifts microbial community abundance and composition. Applied Soil Ecology 111:94-104.

https://doi.org/10.1016/i.apsoil.2016.11.017 


\section{Figure legends}

738 Fig. 1. Mann-Whitney $\mathrm{U}$ test revealing significant differences in soil properties, i.e., contents of organic C, $\mathrm{P}, \mathrm{Ca}^{2+}$, $739 \mathrm{Mg}^{2+}$, and $\mathrm{Fe}^{2+}$ and $\mathrm{pH}$, between the forest (Fr) and grassland ( $\mathrm{Gr}$ ) soils.

740 Fig. 2. A simple logistic regression model revealing significant prediction of the absence (0) and presence (1) of 741 forestation based on the contents of the soil elements.

742 Fig. 3. Divergence of the microbiome between the forest and grassland soils as revealed by (a) hierarchical cluster 743 analysis and (b) discriminant analysis of principal components (DAPC).

744

745 
Figure 1

Mann-Whitney $\mathrm{U}$ test revealing significant differences in soil properties,

i.e., contents of organic $\mathrm{C}, \mathrm{P}, \mathrm{Ca}^{2+}, \mathrm{Mg}^{2+}$, and $\mathrm{Fe}^{2+}$ and $\mathrm{pH}$, between the forest $(\mathrm{Fr})$ and grassland (Gr) soils.

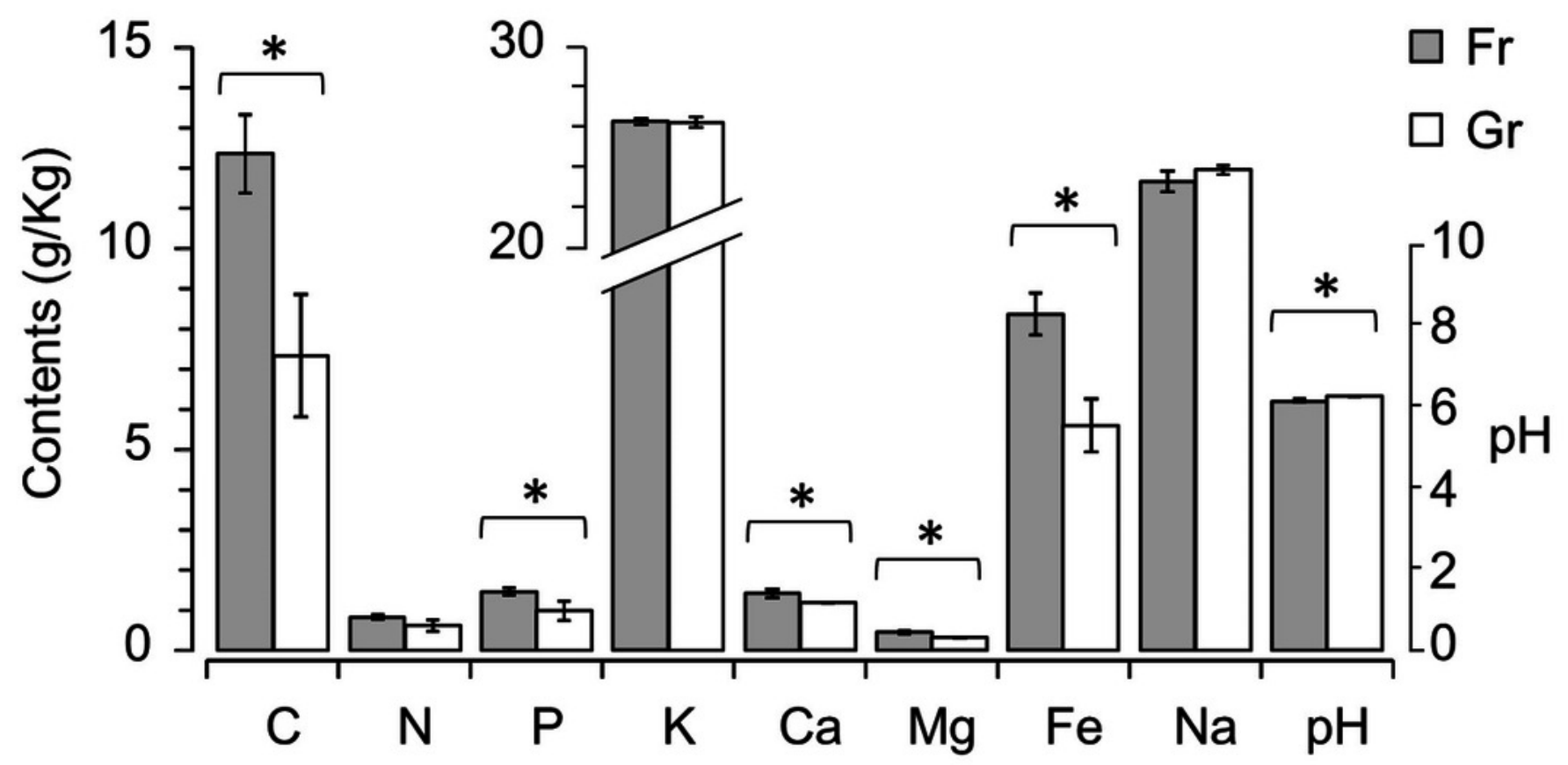


Figure 2

A simple logistic regression model revealing significant prediction of the absence (0) and presence (1) of forestation based on the contents of the soil elements.
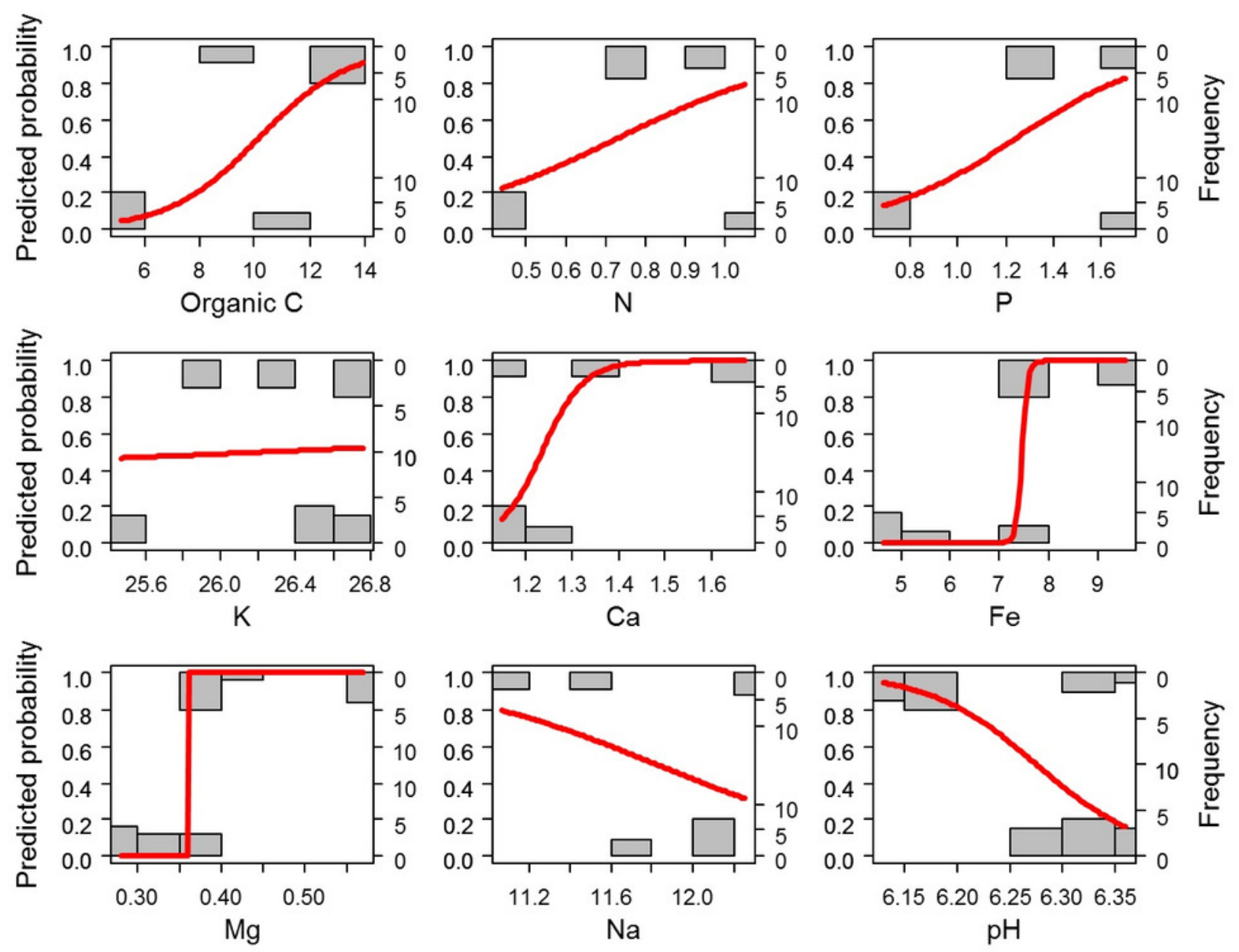
Figure 3

Divergence of the microbiome between the forest and grassland soils as revealed by (a) hierarchical cluster analysis and (b) discriminant analysis of principal components (DAPC).
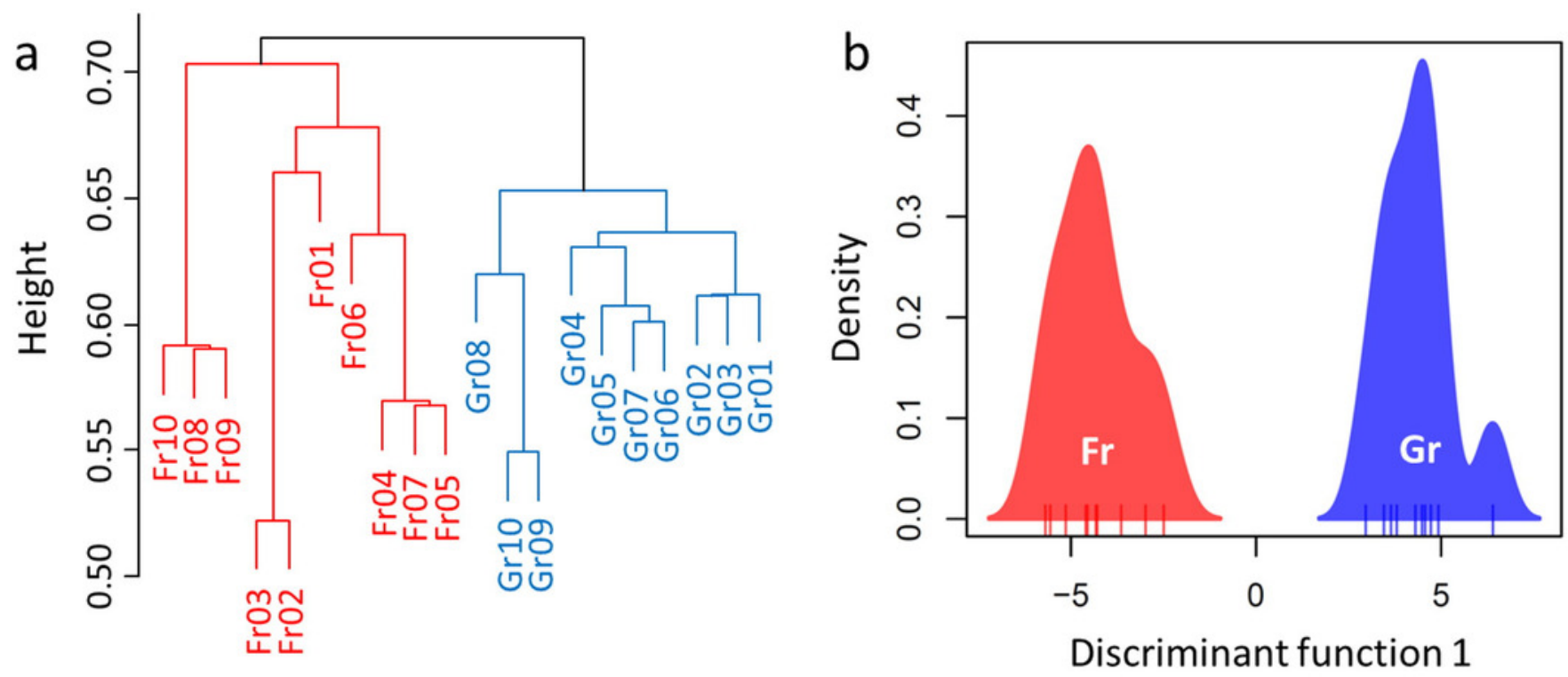


\section{Table $\mathbf{1}$ (on next page)}

Contents of soil elements $\left(\mathrm{g} \mathrm{kg}^{-1}\right)$ and $\mathrm{pH}$ of the forest and grassland soils reported in format of average \pm standard deviation. 
1 Table 1. Contents of soil elements $\left(\mathrm{g} \mathrm{kg}^{-1}\right)$ and $\mathrm{pH}$ of the forest and grassland soils reported in format of average \pm 2 standard deviation.

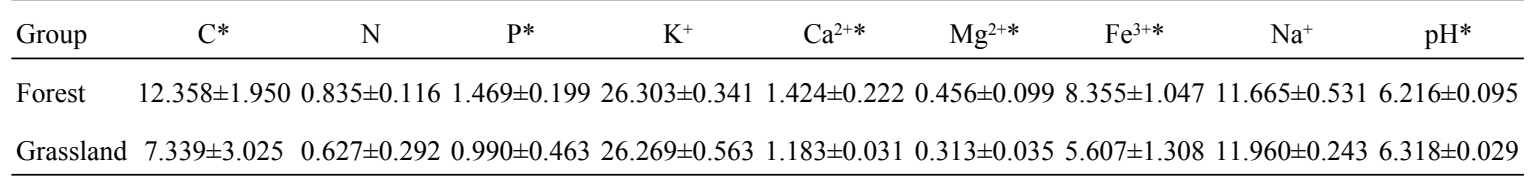

$3 *$ Significant difference between the forest and grassland soils 4 


\section{Table 2 (on next page)}

Summary of the (partial) dbRDA results for the afforestation effect (i.e., vegetation type) on soil properties and on the relative abundance (RA) of soil bacteria.

The effect of soil properties on the bacterial RA was also tested. Type II ANOVA was used to test the model fitting for each independent variable. Significant $P$ values $(<0.05)$ are in bold. 
1 Table 2. Summary of the (partial) dbRDA results for the afforestation effect (i.e., vegetation type) on soil properties 2 and on the relative abundance (RA) of soil bacteria. The effect of soil properties on the bacterial RA was also tested.

3 Type II ANOVA was used to test the model fitting for each independent variable. Significant $P$ values $(<0.05)$ are 4 in bold.

\begin{tabular}{|c|c|c|c|c|}
\hline & \multicolumn{2}{|c|}{ dbRDA } & \multicolumn{2}{|c|}{ ANOVA } \\
\hline & S.S. & Proportion & $F$ & $P$ \\
\hline \multicolumn{5}{|c|}{ Soil property $\sim$ Vegetation type } \\
\hline Constrained & 0.027 & 0.502 & 18.13 & 0.002 \\
\hline Unconstrained & 0.027 & 0.498 & & \\
\hline \multicolumn{5}{|c|}{ Microbial RA Vegetation type } \\
\hline Constrained & 0.849 & 0.163 & 3.504 & 0.001 \\
\hline Unconstrained & 4.362 & 0.837 & & \\
\hline \multicolumn{5}{|c|}{ Microbial RA $\sim$ Vegetation type + Condition (Soil property) } \\
\hline Conditional & 3.356 & 0.644 & & \\
\hline Constrained & 0.194 & 0.037 & 1.053 & 0.466 \\
\hline Unconstrained & 1.661 & 0.319 & & \\
\hline \multicolumn{5}{|c|}{ Microbial RA Soil property } \\
\hline Constrained & 3.356 & 0.644 & & \\
\hline $\mathrm{C}$ & 0.595 & 0.114 & 3.210 & 0.001 \\
\hline $\mathrm{P}$ & 0.524 & 0.100 & 2.823 & 0.001 \\
\hline $\mathrm{Ca}^{2+}$ & 0.467 & 0.090 & 2.516 & 0.001 \\
\hline $\mathrm{Mg}^{2+}$ & 0.368 & 0.071 & 1.986 & 0.003 \\
\hline $\mathrm{Fe}^{3+}$ & 0.546 & 0.105 & 2.940 & 0.001 \\
\hline $\mathrm{pH}$ & 0.228 & 0.044 & 1.232 & 0.145 \\
\hline $\mathrm{N}$ & 0.249 & 0.048 & 1.343 & 0.070 \\
\hline $\mathrm{K}^{+}$ & 0.188 & 0.036 & 1.012 & 0.438 \\
\hline $\mathrm{Na}^{+}$ & 0.190 & 0.037 & 1.026 & 0.365 \\
\hline Unconstrained & 1.855 & 0.356 & & \\
\hline \multicolumn{5}{|c|}{ Microbial RA $\sim$ Soil property + Condition (Vegetation type) } \\
\hline Conditional & 0.849 & 0.163 & & \\
\hline Constrained & 2.701 & 0.518 & & \\
\hline $\mathrm{C}$ & 0.350 & 0.067 & 1.899 & 0.005 \\
\hline $\mathrm{P}$ & 0.493 & 0.095 & 2.673 & 0.001 \\
\hline $\mathrm{Ca}^{2+}$ & 0.457 & 0.088 & 2.477 & 0.001 \\
\hline $\mathrm{Mg}^{2+}$ & 0.350 & 0.067 & 1.896 & 0.004 \\
\hline $\mathrm{Fe}^{3+}$ & 0.283 & 0.054 & 1.534 & 0.009 \\
\hline $\mathrm{pH}$ & 0.203 & 0.039 & 1.102 & 0.238 \\
\hline $\mathrm{N}$ & 0.183 & 0.035 & 0.994 & 0.490 \\
\hline $\mathrm{K}^{+}$ & 0.190 & 0.037 & 1.031 & 0.362 \\
\hline $\mathrm{Na}^{+}$ & 0.190 & 0.036 & 1.029 & 0.378 \\
\hline Unconstrained & 1.661 & 0.319 & & \\
\hline
\end{tabular}




\section{Table $\mathbf{3}$ (on next page)}

Diversity indices comparisons of soil bacterial communities 
1 Table 3. Diversity indices comparisons of soil bacterial communities

\begin{tabular}{lcccc} 
& Forest $($ mean $\pm \mathrm{SD})$ & Grassland (mean $\pm \mathrm{SD})$ & $\mathrm{KW} \chi^{2}$ & $P$ \\
\hline Shannon-Wiener $H$ & $8.429 \pm 0.244$ & $8.612 \pm 0.174$ & 3.291 & 0.070 \\
Reciprocal Simpson's index 1/D & $877.783 \pm 281.326$ & $1190.206 \pm 364.143$ & 4.166 & 0.041 \\
Species richness $(S)$ & $14685.0 \pm 4846.82$ & $13664.6 \pm 2107.68$ & 0 & 1 \\
Pielou's evenness $(J)$ & $0.883 \pm 0.017$ & $0.905 \pm 0.008$ & 9.864 & 0.002 \\
\hline
\end{tabular}

2 
Table 4(on next page)

Effect of soil properties on the abundance of divergent soil microbial phyla inferred by the generalized linear model (GLM).

Significant $P$ values $(<0.05)$ are in bold. 
1 Table 4. Effect of soil properties on the abundance of divergent soil microbial phyla inferred by the generalized

2 linear model (GLM). Significant $P$ values $(<0.05)$ are in bold.

\begin{tabular}{|c|c|c|c|c|c|c|c|c|c|c|}
\hline & \multicolumn{2}{|c|}{ Thaumarchaeota } & \multicolumn{2}{|c|}{ Chloroflexi } & \multicolumn{2}{|c|}{ Fibrobacteres } & \multicolumn{2}{|c|}{ Nitrospirae } & \multicolumn{2}{|c|}{ Parcubacteria } \\
\hline & $t$ value & $P$ & $t$ value & $P$ & $t$ value & $P$ & $t$ value & $P$ & $t$ value & $P$ \\
\hline Intercept & 0.068 & 0.947 & -3.280 & 0.005 & -1.087 & 0.295 & -1.176 & 0.259 & -1.590 & 0.134 \\
\hline $\mathrm{C}$ & -0.288 & 0.778 & 3.501 & 0.004 & 0.632 & 0.538 & 1.471 & 0.164 & 1.714 & 0.109 \\
\hline $\mathrm{P}$ & -0.420 & 0.681 & 4.848 & 0.0003 & 3.735 & 0.002 & 4.108 & 0.001 & 3.326 & 0.005 \\
\hline $\mathrm{Ca}^{2+}$ & -0.083 & 0.935 & 3.857 & 0.002 & 1.267 & 0.226 & 1.667 & 0.118 & 2.007 & 0.065 \\
\hline $\mathrm{Mg}^{2+}$ & 0.031 & 0.976 & -3.727 & 0.002 & -1.174 & 0.260 & -1.374 & 0.191 & -1.934 & 0.074 \\
\hline $\mathrm{Fe}^{3+}$ & 2.088 & 0.056 & -0.332 & 0.745 & -1.263 & 0.227 & -2.900 & 0.012 & -0.575 & 0.574 \\
\hline
\end{tabular}

3 


\section{Table 5 (on next page)}

Table 5. Summary of the (partial) dbRDA results for the afforestation effect (i.e., vegetation type) and soil-property effect on the ecofunction (COGs and KEGG modules) estimated from the soil bacterial communities.

Type II ANOVA was used to test the model fitting for each independent variable. Significant $P$ values $(<0.05)$ are in bold. 
1 Table 5. Summary of the (partial) dbRDA results for the afforestation effect (i.e., vegetation type) and soil-property 2 effect on the ecofunction (COGs and KEGG modules) estimated from the soil bacterial communities. Type II

3 ANOVA was used to test the model fitting for each independent variable. Significant $P$ values $(<0.05)$ are in bold.

\begin{tabular}{|c|c|c|c|c|c|c|c|c|}
\hline & \multicolumn{2}{|c|}{$\mathrm{dbRDA}$} & \multicolumn{2}{|c|}{ ANOVA } & \multicolumn{2}{|c|}{$\mathrm{dbRDA}$} & \multicolumn{2}{|c|}{ ANOVA } \\
\hline & S.S. & Proportion & $F$ & $P$ & S.S. & Proportion & $F$ & $P$ \\
\hline & \multicolumn{4}{|c|}{ COGs Vegetation type } & \multicolumn{4}{|c|}{ KEGG Vegetation type } \\
\hline Constrained & 0.005 & 0.220 & 5.081 & 0.001 & 0.001 & 0.212 & 4.834 & 0.001 \\
\hline \multirow[t]{2}{*}{ Unconstrained } & 0.016 & 0.780 & & & 0.002 & 0.788 & & \\
\hline & \multicolumn{4}{|c|}{ COGs $\sim$ Vegetation type + Condition (Soil property) } & \multicolumn{4}{|c|}{$\begin{array}{l}\text { KEGG Vegetation type + Condition (Soil } \\
\text { property) }\end{array}$} \\
\hline Conditional & 0.017 & 0.830 & & & 0.003 & 0.824 & & \\
\hline Constrained & 0.001 & 0.034 & 2.267 & 0.078 & $1 \mathrm{E}-04$ & 0.045 & 3.140 & 0.038 \\
\hline \multirow[t]{2}{*}{ Unconstrained } & 0.003 & 0.136 & & & $4 \mathrm{E}-04$ & 0.130 & & \\
\hline & \multicolumn{4}{|c|}{ COGs $\sim$ Soil property } & \multicolumn{4}{|c|}{ KEGG Soil property } \\
\hline Constrained & 0.017 & 0.830 & & & 0.003 & 0.824 & & \\
\hline $\mathrm{C}$ & 0.002 & 0.094 & 5.541 & 0.001 & $3 \mathrm{E}-04$ & 0.097 & 5.5051 & 0.001 \\
\hline $\mathrm{P}$ & 0.003 & 0.140 & 8.234 & 0.001 & 0.001 & 0.165 & 9.3958 & 0.001 \\
\hline $\mathrm{Ca}$ & 0.003 & 0.140 & 8.247 & 0.001 & $3 \mathrm{E}-04$ & 0.107 & 6.0938 & 0.001 \\
\hline $\mathrm{Mg}$ & 0.002 & 0.072 & 4.252 & 0.005 & $1 \mathrm{E}-04$ & 0.042 & 2.4047 & 0.063 \\
\hline $\mathrm{Fe}$ & 0.002 & 0.073 & 4.273 & 0.010 & $2 \mathrm{E}-04$ & 0.066 & 3.738 & 0.013 \\
\hline $\mathrm{pH}$ & $5 \mathrm{E}-04$ & 0.023 & 1.347 & 0.283 & $9 \mathrm{E}-05$ & 0.028 & 1.5886 & 0.177 \\
\hline $\mathrm{N}$ & 0.005 & 0.258 & 15.157 & 0.001 & 0.001 & 0.292 & 16.615 & 0.001 \\
\hline $\mathrm{K}$ & $2 \mathrm{E}-04$ & 0.010 & 0.575 & 0.653 & $4 \mathrm{E}-05$ & 0.012 & 0.6817 & 0.580 \\
\hline $\mathrm{Na}$ & $4 \mathrm{E}-04$ & 0.020 & 1.174 & 0.312 & $5 \mathrm{E}-05$ & 0.016 & 0.914 & 0.453 \\
\hline \multirow[t]{2}{*}{ Unconstrained } & 0.004 & 0.170 & & & 0.001 & 0.176 & & \\
\hline & \multicolumn{4}{|c|}{ COGs $\sim$ Soil property + Condition (Vegetation type) } & \multicolumn{4}{|c|}{$\begin{array}{l}\text { KEGG Soil property + Condition (Vegetation } \\
\text { type) }\end{array}$} \\
\hline Conditional & 0.005 & 0.220 & & & 0.001 & 0.212 & & \\
\hline Constrained & 0.013 & 0.644 & & & 0.002 & 0.658 & & \\
\hline $\mathrm{C}$ & 0.001 & 0.027 & 1.776 & 0.152 & $7 \mathrm{E}-05$ & 0.021 & 1.478 & 0.257 \\
\hline $\mathrm{P}$ & 0.004 & 0.172 & 11.371 & 0.001 & $5 \mathrm{E}-04$ & 0.157 & 10.877 & 0.001 \\
\hline $\mathrm{Ca}$ & 0.001 & 0.071 & 4.723 & 0.006 & $2 \mathrm{E}-04$ & 0.061 & 4.226 & 0.018 \\
\hline $\mathrm{Mg}$ & 0.001 & 0.030 & 1.963 & 0.133 & $8 \mathrm{E}-05$ & 0.027 & 1.869 & 0.175 \\
\hline $\mathrm{Fe}$ & 0.005 & 0.251 & 16.630 & 0.001 & 0.001 & 0.264 & 18.238 & 0.001 \\
\hline $\mathrm{pH}$ & 0.001 & 0.032 & 2.094 & 0.110 & $1 \mathrm{E}-04$ & 0.038 & 2.650 & 0.066 \\
\hline $\mathrm{N}$ & $4 \mathrm{E}-04$ & 0.018 & 1.162 & 0.302 & 9E-05 & 0.028 & 1.946 & 0.130 \\
\hline $\mathrm{K}$ & $3 \mathrm{E}-04$ & 0.014 & 0.928 & 0.406 & $7 \mathrm{E}-05$ & 0.022 & 1.510 & 0.223 \\
\hline $\mathrm{Na}$ & 0.001 & 0.030 & 2.017 & 0.141 & $1 \mathrm{E}-04$ & 0.039 & 2.691 & 0.070 \\
\hline Unconstrained & 0.003 & 0.136 & & & 4E-04 & 0.130 & & \\
\hline
\end{tabular}




\section{Table 6(on next page)}

Deviance of the species-rank abundance distribution (RAD) models revealing the best fits of the Mandelbrot or Zipf-Mandelbrot model for all sampled soil microbial communities.

The lowest Akaike Information Criterion (AIC) 
1 Table 6. Deviance of the species-rank abundance distribution (RAD) models revealing the best fits of the

2 Mandelbrot or Zipf-Mandelbrot model for all sampled soil microbial communities. The lowest Akaike Information

\begin{tabular}{lcccccccccc}
\hline & Gr01 & Gr02 & Gr03 & Gr04 & Gr05 & Gr06 & Gr07 & Gr08 & Gr09 & Gr10 \\
\hline Null & 23473.2 & 24412.6 & 20882.8 & 21609.8 & 29653.7 & 23972.9 & 16175.0 & 21291.9 & 25119.2 & 31461.4 \\
Preemption & 28921.1 & 30018.9 & 25494.1 & 26779.2 & 36675.8 & 29667.9 & 19209.2 & 26001.7 & 30809.4 & 38768.3 \\
Lognormal & 9527.5 & 11539.7 & 9701.5 & 10157.8 & 12942.7 & 10585.8 & 7802.7 & 9847.3 & 10650.6 & 13265.6 \\
Zipf & 1652.7 & $\mathbf{1 2 0 1 . 5}$ & 1168.1 & $\mathbf{1 0 1 0 . 2}$ & 1722.0 & 1421.0 & 1016.5 & 1169.2 & 2228.9 & 2215.5 \\
Mandelbrot & $\mathbf{1 0 5 7 . 1}$ & $\mathbf{1 2 0 1 . 5}$ & $\mathbf{1 0 1 0 . 8}$ & $\mathbf{1 0 1 0 . 2}$ & $\mathbf{1 5 2 5 . 2}$ & $\mathbf{1 1 6 5 . 6}$ & $\mathbf{9 1 9 . 3}$ & $\mathbf{9 6 0 . 8}$ & $\mathbf{1 0 5 0 . 2}$ & $\mathbf{1 3 3 8 . 9}$ \\
\hline
\end{tabular}

3 Criterion (AIC) values representing the best fit model are shown in bold.

4

\begin{tabular}{lcccccccccc}
\hline & Fr01 & Fr02 & Fr03 & Fr04 & Fr05 & Fr06 & Fr07 & Fr08 & Fr09 & Fr10 \\
\hline Null & 16276.4 & 37243.8 & 90272.5 & 29118.5 & 45159.8 & 20701.9 & 30670.6 & 30757.4 & 24744.7 & 56299.3 \\
Preemption & 19814.6 & 46031.3 & 109349.0 & 36030.8 & 55651.5 & 25626.1 & 37854.4 & 38189.6 & 30699.1 & 68945.4 \\
Lognormal & 7617.4 & 15371.2 & 30465.1 & 12328.5 & 18347.1 & 9072.1 & 12376.0 & 12888.0 & 10492.1 & 21309.7 \\
Zipf & 1299.5 & 2431.4 & 4527.6 & 1944.1 & 3573.2 & 1244.4 & 1894.5 & 1351.4 & 1220.3 & 2186.6 \\
Mandelbrot & $\mathbf{8 6 7 . 4}$ & $\mathbf{1 6 9 9 . 7}$ & $\mathbf{3 0 4 3 . 8}$ & $\mathbf{1 2 4 8 . 1}$ & $\mathbf{2 0 8 0 . 9}$ & $\mathbf{8 8 3 . 3}$ & $\mathbf{1 2 4 5 . 9}$ & $\mathbf{1 2 8 5 . 5}$ & $\mathbf{1 0 9 2 . 0}$ & $\mathbf{1 8 9 7 . 3}$ \\
\hline
\end{tabular}

5

6

7

8

9

10 